\title{
Spatial analysis of toxoplasmosis through EcoHealth approaches using GRA-1 recombinant: case in Sleman, Yogyakarta
}

\author{
Fihiruddin ${ }^{1}$, Wayan Tunas Artama ${ }^{2,3,{ }^{*}}$, and Barandi Sapta Widartono ${ }^{1,4}$ \\ ${ }^{1}$ Department of Medical Laboratory Technology, Politeknik Kesehatan Mataram, Praburangkasari Street, Sandubaya, Mataram 83232 , \\ Indonesia \\ ${ }^{2}$ One Health/EcoHealth Resource Center, Universitas Gadjah Mada, Barek, Teknika Utara Street, Kocoran, Sleman, Yogyakarta 55281, \\ Indonesia \\ ${ }^{3}$ Department of Biochemistry, Faculty of Veterinary Medicine, Universitas Gadjah Mada, Fauna Street No. 2, Caturtunggal, Sleman, \\ Yogyakarta 55281, Indonesia \\ ${ }^{4}$ Departement of GISRP, Faculty of Geography, Universitas Gadjah Mada, Kaliurang Street, Sinduadi, Sleman, Yogyakarta 55281, Indonesia \\ ${ }^{*}$ Corresponding author: artama@ugm.ac.id
}

SUBMITTED 22 October 2019 REVISED 7 May 2020 ACCEPTED 16 September 2020

\begin{abstract}
Toxoplasmosis is an obligate intracellular zoonotic parasite caused by Toxoplasma gondii that can infect all warm-blooded animals including humans. Prevalence of toxoplasmosis varies depending on climate, geography, and the presence of cats in an area. This study aimed to identify the prevalence and distribution of toxoplasmosis in Sleman, Yogyakarta through EcoHealth approaches. A total of 385 blood samples were collected from residents in the district of Sleman. Seven people from 55 villages were selected for blood sampling using a cluster method. The collected serums were tested by ELISA using recombinant Granule 1 protein (GRA-1) as coated antigen. Data on altitude and coordinates of sampling sites were collected using GPS instruments, soil surface temperature in Sleman was obtained by satellite imagery, and cat population in residential areas was determined by questionnaire. The prevalence of toxoplasmosis in Sleman was $58 \%$, of which distributed around rivers and in cattle pens. Based on altitude and temperature, toxoplasmsosis cases were found the highest at $0-150 \mathrm{~m}(66.3 \%)$ and at temperatures of $26-30{ }^{\circ} \mathrm{C}(66.4 \%)$. Areas with large numbers of cats had toxoplasmosis prevalence of $75.8 \%$ while areas with moderate and few cats were $56.5 \%$ and $49.0 \%$, respectively. Thus, differences in the prevalence of toxoplasmosis at settlement were found based on altitude, soil surface temperature and cat populations.
\end{abstract}

KEYWORDS EcoHealth; GPS; GRA-1; toxoplasmosis

\section{Introduction}

Toxoplasmosis is an important parasitic zoonosis caused by Toxoplasma gondii which is distributed worldwide, except in polar regions and desert areas. Zoonoses is a disease transmitted between human and animals. Warmblooded animals, including humans and other mammals are the intermediate hosts, while cats and other of Felidae are definitive hosts (Tenter et al. 2000; Lopes et al. 2011). The prevalence of cats exposed to toxoplasmosis in Indonesia was 35-73\%, while in Yogyakarta is $40 \%$ (Agustin and Mukono 2016). The serological studies in farm animals around the world showed that toxoplasmosis is commonly found in cattle (14\%), goats (27\%), pigs (25\%), sheep (66\%), and horses (14\%). The prevalence of toxoplasmosis in goats and cattle in Yogyakarta was $78 \%$ and 21\%, respectively (Sujono 2010; Retmanasari et al. 2017). The worldwide prevalence of toxoplasmo- sis varies, depending on climate, geography, and the presence of cats in an area. The seropositive of T. gondii using ELISA test in adults human worldwide is $13-59 \%$, in the USA is $10-59 \%$, while Europe and Brazil reported approximately 50-80\% were infected (Jones et al. 2001). At several places in Indonesia, the prevalence of toxoplasmosis varies between 43-88\% (Subekti and Arrasyid 2006). Toxoplasmosis in humans and animals often shows subclinical symptomatic or asymptomatics, so that they can be unwittingly infected by toxoplasmosis. Humans can be infected by T. gondii through food, undercooked meat, and vegetables contaminated by oocysts or congenital transmission from pregnant mother to fetus in the womb. The congenital transmission does occur and may lead to severe problems in unborn children and babies, including abortion, hydrocephalus, and retinochoroiditis (ChacinBonilla et al. 2001; Sukthana 2006; Sadiqui et al. 2019).

Human has been associated closely with animal for 
many centuries. This close relationship between human and animal can induce antropozoonosis diseases such as toxoplasmosis. The occurrence of zoonotic diseases can be affected by changes in weather, climate, and environmental conditions. The environment includes everything outside the relevance of organisms such as sunlight, temperature, humidity, topology, vegetation, rainfall and competitors. Therefore, to handle the zoonotic disease, it should be controlled in human, animal, and environmental health aspects. Culture, social, economic and ecological situations has an interrelated with health and diseases. Lifestyle, socio-demographic and environment are risk factors for toxoplasmosis. EcoHealth is one of several integrative approaches that consider interactions between human health, animal health and the environment. Interdisciplinary collaborative research is essential to reduce zoonosis such as toxoplasmosis (Retmanasari et al. 2017). Ecosystem approach to human health is the study of environmental change in biological, physical, social and economic factors, and linking these changes to their impact on human health. Ecosystem is the habitat of a particular species when it possesses the ability to support the life of the species. The relationship of $T$. gondii with humans, animals and the environment has an interdependent relationship to maintain their life sustainability. Toxoplasma gondii requires cat-like animals to keep its viability (Rapport 2007; Meerburg and Kijlstra 2009). As the definitive host, cats play an important role in transmitting toxoplasmosis to cattle, wildlife and humans. Toxoplasmosis occurs when the oocysts are released along with cats stool, which can contaminate the surrounding environment. These oocysts will survive in the environment for a long time, depend on soil conditions (moisture, sunlight, temperature and humidity) and stability of the surrounding ecology, including the presence of definitive hosts and intermediate hosts of T. gondii (Jones et al. 2001; Chahaya 2003).

The study about the prevalence of toxoplasmosis comparing various risk factors has been conducted in several countries and showed highly variable results. The most dominant risk factor for toxoplasmosis infection can not be determined exactly to date. Nevertheless, there is no study about the relationship toxoplasmosis incidence with geographical dissemination of toxoplasmosis, environmental changes, especially in Sleman regions, Yogyakarta, Indonesia. The changes in environmental conditions including temperature, topography region, the presence of farm animals and distribution of the population can negatively affect the prevalence of toxoplasmosis. Thus it is necessary to study the prevalence of toxoplasmosis in Sleman through EcoHealth approach. Analysis of the prevalence of toxoplasmosis in Sleman through EcoHealth approach can be performed using remote sensing technologies and mapping by Geographic Information Systems (GIS) for the detection of vulnerable populations and environmental diseases. Utilization of GIS to provide spatial data that describes the distribution or pattern of disease spread, to understand prevalence and populations at risk for a dis- ease, that was observed based on the concept of EcoHealth (Chivian 2001; Sujono 2010; Dong et al. 2018).

Nowadays, the diagnosis of toxoplasmosis carried out using serological and molecular tests. Several serological tests have been developed to detect specific antibodies against $T$. gondii in humans and animals. Immunodeterminant antigens of the toxoplasma protein can stimulate the host immune response. ELISA is one of the tests used to detect existing of toxoplasmosis in humans and animals. The basic principle of this method is to detect the presence of immunoglobulin in the serum with $T$. gondii specific antigens. Granule 1 (GRA-1) protein is an immunogenic granule protein of T.gondii and is most expressed compared to other GRA proteins. GRA-1 protein can be found on the parasitophorous vacuole membrane, the vacuole matrix and tubular structures in the T. gondii parasitophorous vacuole (Subekti 2014; Muflikhah and Artama 2017). GRA-1 protein from local isolates showed equivalent virulence with $T$. gondii $\mathrm{RH}$ strain in experimental mice (Subekti et al. 2008). These proteins can be used as a vaccine candidate and diagnostic tool because GRA-1 has the capability to induce humoral and cellular immune response in both human and mice (Wihadmadyatami et al. 2011). One way to get pure GRA-1 protein is recombinant protein through the cloning approach and expression of GRA-1 protein-coding gene (Subekti 2014; Muflikhah and Artama 2017). The aims of this study are to measure the prevalence and distribution of toxoplasmosis in the Sleman region through EcoHealth approaches and the effect of altitude, soil surface temperature and the presence of cats in the surrounding human residential areas against the prevalence of toxoplasmosis using GRA-1 recombinant proteins.

\section{Materials and Methods}

\subsection{Design and sampling}

This study was an analytical survey with a cross-sectional design. Blood samples were obtained from 385 respondents in Sleman district, Yogyakarta and then serum was kept at $-20^{\circ} \mathrm{C}$. The choice of respondents performed with two cluster sample design stage, probability proportionate to size (PPS) and simple random sampling. Research clusters were grouped into 55 sections, and 7 people at each cluster were selected for blood sampling. The samples were examined by ELISA method using GRA-1 protein tachyzoite locally isolated in the Laboratory of Biochemistry, Center for Biotechnology, Universitas Gadjah Mada. Optical density was measured by a microplate reader (Zenix, ZN-320, China) at $405 \mathrm{~nm}$ of wavelength. Ethical clearance was obtained from the Ethical Clearance Commission of the Faculty of Medicine, Universitas Gadjah Mada (approval number: KE/FK/318/EC). The sample size was calculated by the following formula:

$$
n=\frac{\left(p \times q \times z^{2}\right)}{d^{2}}
$$

Whereas $n$ is the sample size of the research, $p$ is the ex- 
pected proportion in population-based on previous studies, $\mathrm{z} 1-\mathrm{p}$ is standard normal variation $[\alpha=5 \%(1,96)]$, and $d$ is the absolute error (0.05).

\subsection{Expression and purification of GRA-1 proteins}

Recombinant plasmid (pET32+) that contain gene encoding for GRA-1 protein were transformed to E. coli BL21 (DE3). Two milliliters of starter colony containing recombinant plasmids (pET-32a (+)/R1) were cultured in LB liquid medium ( $25 \mathrm{~mL}$ ) supplemented with $25 \mathrm{mg} / \mathrm{mL}$ ampicillin at $37^{\circ} \mathrm{C}$ overnight. Furthermore, $10 \mathrm{~mL}$ bacterial suspension inoculated to $100 \mathrm{~mL} \mathrm{LB}$ medium at $37{ }^{\circ} \mathrm{C}$ to reached optical density $0.600(\mathrm{OD}=0.600)$, and added $1 \mathrm{mM}$ isopropyl-1-thio- $\beta$-Dgalactopyranoside (IPTG) to culture and incubate for $4 \mathrm{~h}$. A total of $20 \mathrm{~mL}$ of bacterial suspension was removed to a new tube and centrifuged at $4{ }^{\circ} \mathrm{C}$ 3,000 rpm for $20 \mathrm{~min}$. The supernatant was removed, and the pellets were washed by phosphate buffer saline (PBS). Centrifugation at $4{ }^{\circ} \mathrm{C} \mathrm{3,000} \mathrm{rpm} \mathrm{for} 10 \mathrm{~min}$ and washing pellets using PBS three times were carried out. The pellets were dissolved with $500 \mu \mathrm{L}$ PBS solution and destroyed by sonication. Finally, the supernatants were collected by centrifugation at $4{ }^{\circ} \mathrm{C}, 10,000 \mathrm{rpm}$ for $5 \mathrm{~min}$.

The GRA-1 recombinant proteins were purified using nickel column chromatography and the purified lysate was loaded into a $10 \mathrm{~mL}$ Ni-NTA column (Ni-NTA Purification System, NOVEX by Lab Technologies Cat No. K95001, USA). Initially, the column was washed with wash buffer $\left(250 \mathrm{mMNaH}_{2} \mathrm{PO}_{4}, 2.5 \mathrm{M} \mathrm{NaCl}\right.$ and $100 \mu \mathrm{L} 3 \mathrm{M}$ imidazole). The proteins were eluted with elution buffer (250 $\mathrm{mMNaH}_{2} \mathrm{PO}_{4}, 2.5 \mathrm{M} \mathrm{NaCl}$, and $1.25 \mathrm{~mL} 3 \mathrm{M}$ imidazole). The purified recombinant proteins and supernatant of cell pellets were analyzed using $15 \%$ sodium dodecyl sulfate-polyacrylamide gels (SDS-PAGE). The protein samples were taken and then added with loading dye with a ratio of 1:4 (10 $\mu \mathrm{L}$ loading dye:40 $\mu \mathrm{L}$ sample), then heated at $80{ }^{\circ} \mathrm{C}$ for $5 \mathrm{~min}$. Electrophoresis was performed at $120 \mathrm{~V}$ for $2 \mathrm{~h}$. The proteins were visualized by staining with Coomassie blue for $1 \mathrm{~h}$ using a shaker. The gel was washed with aquabidest, then washed with a staining washing solution (50\% methanol, 10\% acetic acid glacial, and $40 \%$ aquabidest) for 30 min until the band was clearly visible.

\subsection{ELISA assay}

Initially, ELISA plates (Nickel Chelated Plates, Nunc. USA) were washed three times with $300 \mathrm{~mL}$ PBS-T [PBS ( $\mathrm{pH} 7.3$ ) containing $0.05 \%(\mathrm{v} / \mathrm{v})$ Tween 20], and the purified recombinant proteins (GRA-1) were coated overnight at $4{ }^{\circ} \mathrm{C}$ in $100 \mathrm{~mL}$ PBS (concentration of each recombinant proteins was $5 \mu \mathrm{g} / \mathrm{mL}$ ). Plates were washed and blocked ( $5 \%$ serum bovine albumin in $0.05 \%$ PBS-T) at $37{ }^{\circ} \mathrm{C}$ for $1 \mathrm{~h}$. After washing the plate three times with washing solution, $50 \mu \mathrm{L}$ serum diluted one in blocking solution (1:100) was added to duplicate wells for each sample and kept at 37 ${ }^{\circ} \mathrm{C}$ for $1 \mathrm{~h}$. The plates were then washed five times and incubated with $50 \mu \mathrm{L}$ of horseradish peroxidase-conjugated goat anti-human IgG (Sigma, St.Louis, USA) diluted in blocking solution $(1: 4,000)$ per well at $37^{\circ} \mathrm{C}$ for $1 \mathrm{~h}$. After washing five times, the 96 well plates were incubated with $100 \mu \mathrm{L}$ p-NitroPhenyl Phosphate (pNPP) substrate at $37^{\circ} \mathrm{C}$ for $15 \mathrm{~s}$. The absorbance was detected at $405 \mathrm{~nm}$ using a microplate reader.

\subsection{Data analysis}

The ELISA data were collected and calculated based on the mean optical densities at a value of 405. Data on altitude and co-ordinates of sampling sites were taken using a GPS instrument (GPS Garmin ETREX 10, Russian). Land surface temperature in Sleman was obtained by satellite imagery (CITRA ASTER), while cats population data in residential areas were taken through charging questionnaire by respondents. Data analysis was performed by Chi Square and Logistic Binary Regression with 95\% level of confidence and the geographic distribution of toxoplasmosis is made spatially and analyzed by plotting ordinate points of toxoplasmosis, buffering and overlay of a map.

\section{Results and Discussion}

\subsection{Result}

The expression of GRA-1 T. gondii locally isolates in $E$. coli BL21 (DE3) using pET-32a (+)/R1 plasmid is shown in Figure 1. Sodium dodecyl sulfate polyacrylamide gel electrophoresis (SDS-PAGE) of the unpurified GRA-1 recombinant proteins in Figure 1 showed that the molecular weights were $24 \mathrm{kDa}$, accordance with Western blotting assay. The pure of GRA-1 proteins used for ELISA test to evaluating the prevalence and distribution of toxoplas-

TABLE 1 Seroprevalence distribution of toxoplasmosis in each subdistrict in Sleman, Yogyakarta.

\begin{tabular}{llll}
\hline Sub-district & $\begin{array}{l}\text { Amount of sample } \\
\text { (people) }\end{array}$ & Positive test & \% positive \\
\hline Turi & 42 & 20 & 47 \\
Pakem & 49 & 16 & 32 \\
Cangkringan & 56 & 34 & 60 \\
Tempel & 28 & 19 & 57 \\
Sleman & 14 & 17 & 57 \\
Ngaglik & 7 & 4 & 57 \\
Ngamplak & 42 & 25 & 59 \\
Minggir & 21 & 8 & 38 \\
Seyegan & 14 & 6 & 42 \\
Mlati & 7 & 5 & 71 \\
Kalasan & 7 & 4 & 57 \\
Moyudan & 14 & 12 & 85 \\
Godeaan & 21 & 18 & 85 \\
Gamping & 28 & 24 & 85 \\
Depok & 14 & 11 & 78 \\
Berbah & 7 & 5 & 71 \\
Prambanan & 14 & 94 \\
\hline Total & 385 & 224 & \\
\hline & & 58 & 5 \\
\hline
\end{tabular}



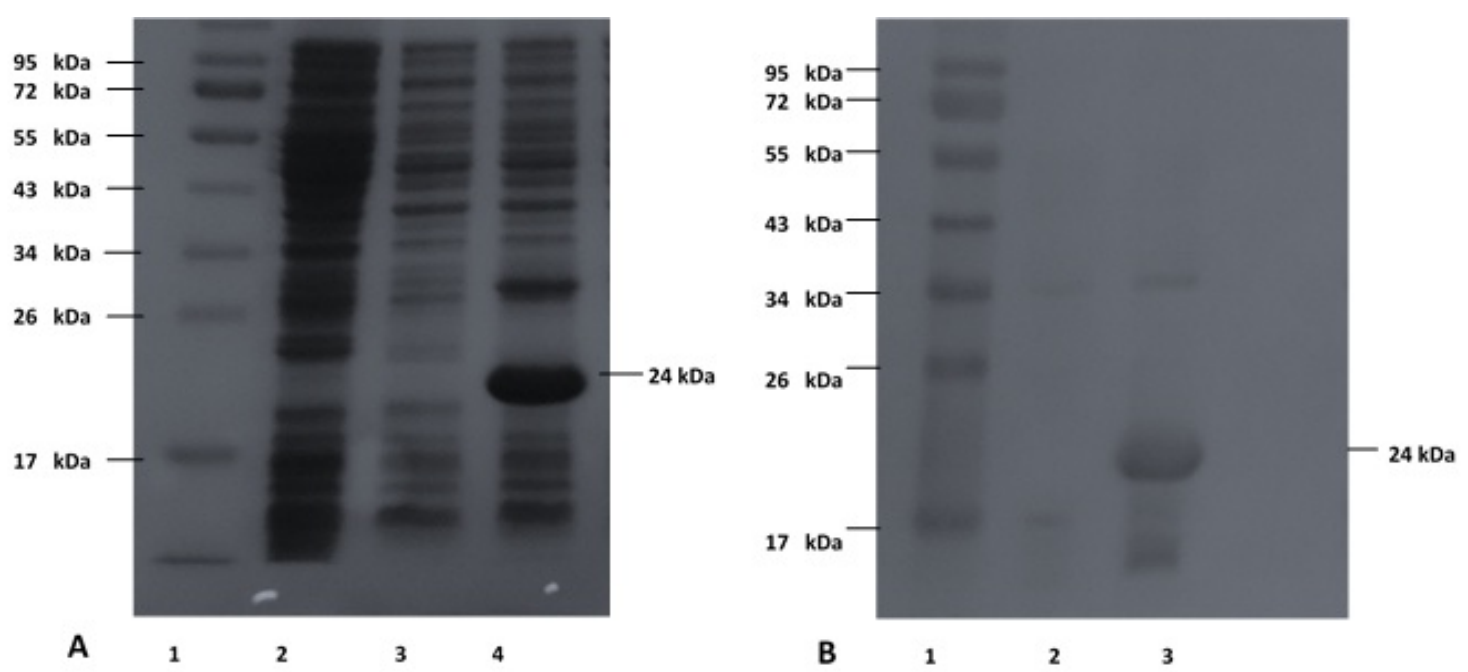

FIGURE 1 SDS-PAGE of GRA-1 proteins of T.gondii. Line 1: protein marker, line 2: negative control ( lysate of E. coli BL21 without plasmid32a(+)), line: 3: lysate of E. coli BL21 without the addition of IPTG, and line 4: unpurified GRA-1 proteins (A). Western blotting of GRA-1 proteins by using $6 x$ anti-histidine Tag monoclonal antibody. Line 1: protein marker, line 2: negative control (lysate of E. coli BL21 without plasmid-32a(+)), line 3: a purified GRA-1 protein (B).

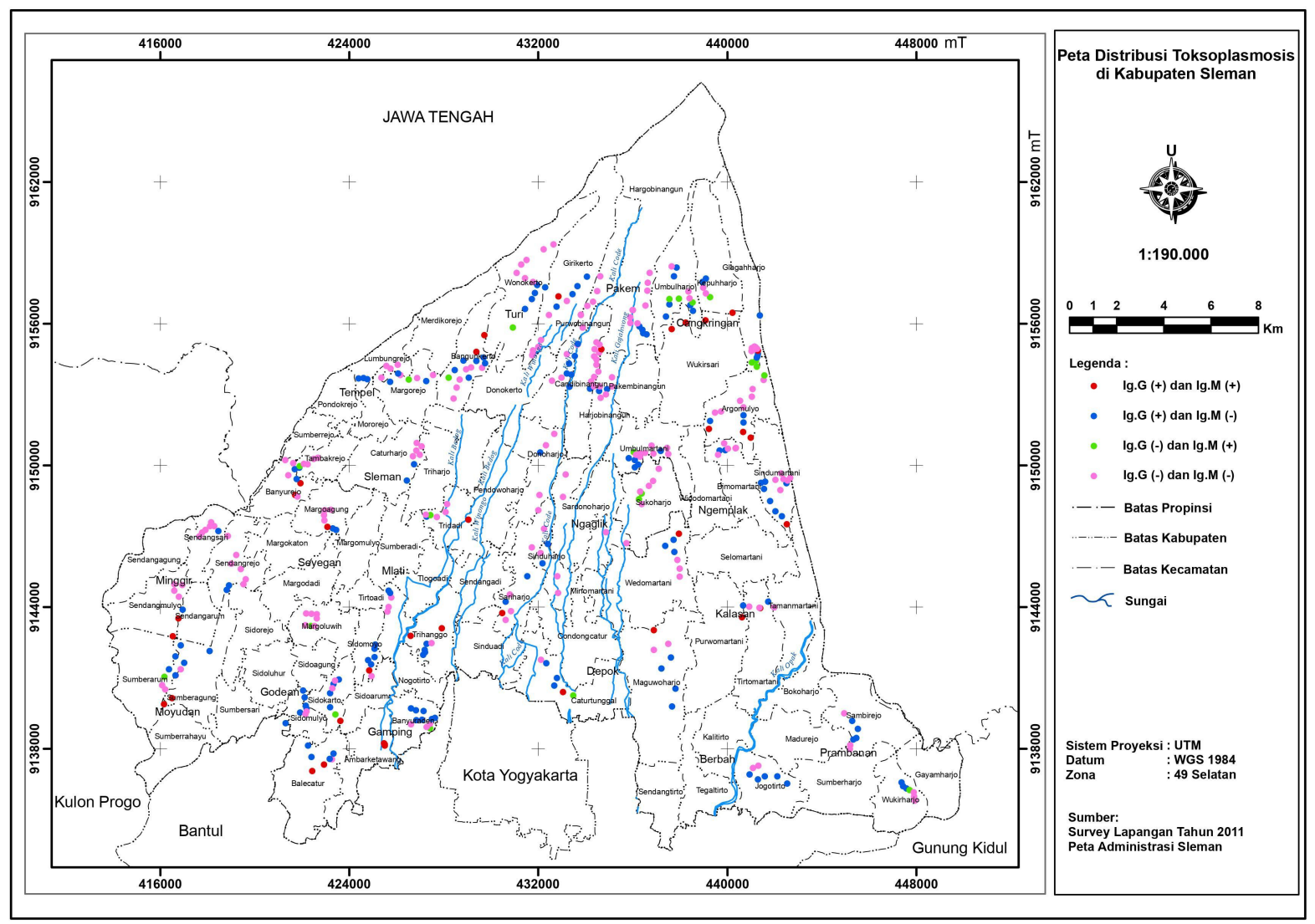

FIGURE 2 Distribution of toxoplasmosis in around the river flow (blue) in Sleman District. Prevalance of toxoplasmosis in human who life near the rivershed were 59.2\% ( $25 \mathrm{~m}$ from river), 54.8\% (50 $\mathrm{m}$ from river), and $46.1 \%$ (100 $\mathrm{m}$ from river) respectively.

mosis in the Sleman district. The prevalence of toxoplasmosis in Sleman after the volcano eruption of Merapi was 58\% (Table 1). The seroprevalence difference of toxoplasmosis in each sub-district in Sleman was related to the behavior, environmental conditions and demographics of the community in each district. The risk factors that greatly influence the prevalence of toxoplasmosis incidences in an area were behavioral, geographic environment and the presence of cats. The toxoplasmosis distribution in subdistrict of Sleman, Yogyakarta are presented in Table 1, 
and the case of toxoplasmosis based on behavioral, geographic environment and the presence of cats are presented in Table 2 (bivariate analysis).

The significant result from bivariate analysis continued to multivariate analysis and the result of odds ratio are shown in (Table 3). Surface temperature and population of cats had Odds ratio more than one. Among that, the population of cats was the highest risk factor. Results of the Multivariate test by Binary Logistic Regression showed that the Odds Ratio of the cat population in the settlements has the most effective when compared to other environmental factors (1.729). These different results are associated with population density.

The distance between river shed and cattle pens is one of risk factors that supports toxoplasmosis accurance in Sleman District (Table 4). The results of disease mapping showed that the most incidence of toxoplasmosis are around the river (Figure 2). Inhabitant settlement close to the cage farms were positive for toxoplasmosis (Figure 3). The purple color is the nearest settlement from the farm and the green color is furthest from farms. More than 20\% of respondents live around the farms.

Toxoplasmosis was higher in lowland (0-500 m) than highland (>500 m) (Figure 4). The dark brown location (sepia and brown) showed highland whle the light brown (russet) shows lowland. Another risk factor observed in this study was temperature. The variation temperature in this study is shown in Figure 5. The results of satellite imagery, and ground surface temperature in Sleman, Yogyakarta are ranged between $23^{\circ} \mathrm{C}-36^{\circ} \mathrm{C}$. The results of IgM and IgG anti toxoplasma tests are based on differences of temperature, which showed significant results among several soil surface temperatures in the value was 0.023 ( $\mathrm{P}$ value $<0.05$ ). The orange color is the highest cases of toxoplasmosis in the Sleman District $\left(26^{\circ} \mathrm{C}-30^{\circ} \mathrm{C}\right)$. Population cats in Sleman District are one of the risk factors in this study (Figure 6). The brown color showed that many cats could be found in that location.

\subsection{Discussion}

Granule protein is a major component of excretory and secretory antigen (ESA) secreted by organelles T. gondii, and these proteins play an essential role during the invasion of the parasites into the host cells (Subekti 2014). The GRA-1 protein-induced humoral and cellular immune responses of the host. The availability of GRA-1 protein for the purposed diagnosis is very limited. Therefore, over-expression of GRA-1 by subclone of the corresponding gene in the pET 32a will be very beneficial for diagnostic development. The results showed that recombinant GRA-1 protein could be isolated and characterized by electrophoresis $24 \mathrm{kDa}$ and detected by its specific antibody anti T. gondii through immunoblotting. In this study, recombinant proteins of GRA-1 T. gondii from local isolate were used to determine the distribution and the prevalence of toxoplasmosis in Sleman, Yogyakarta

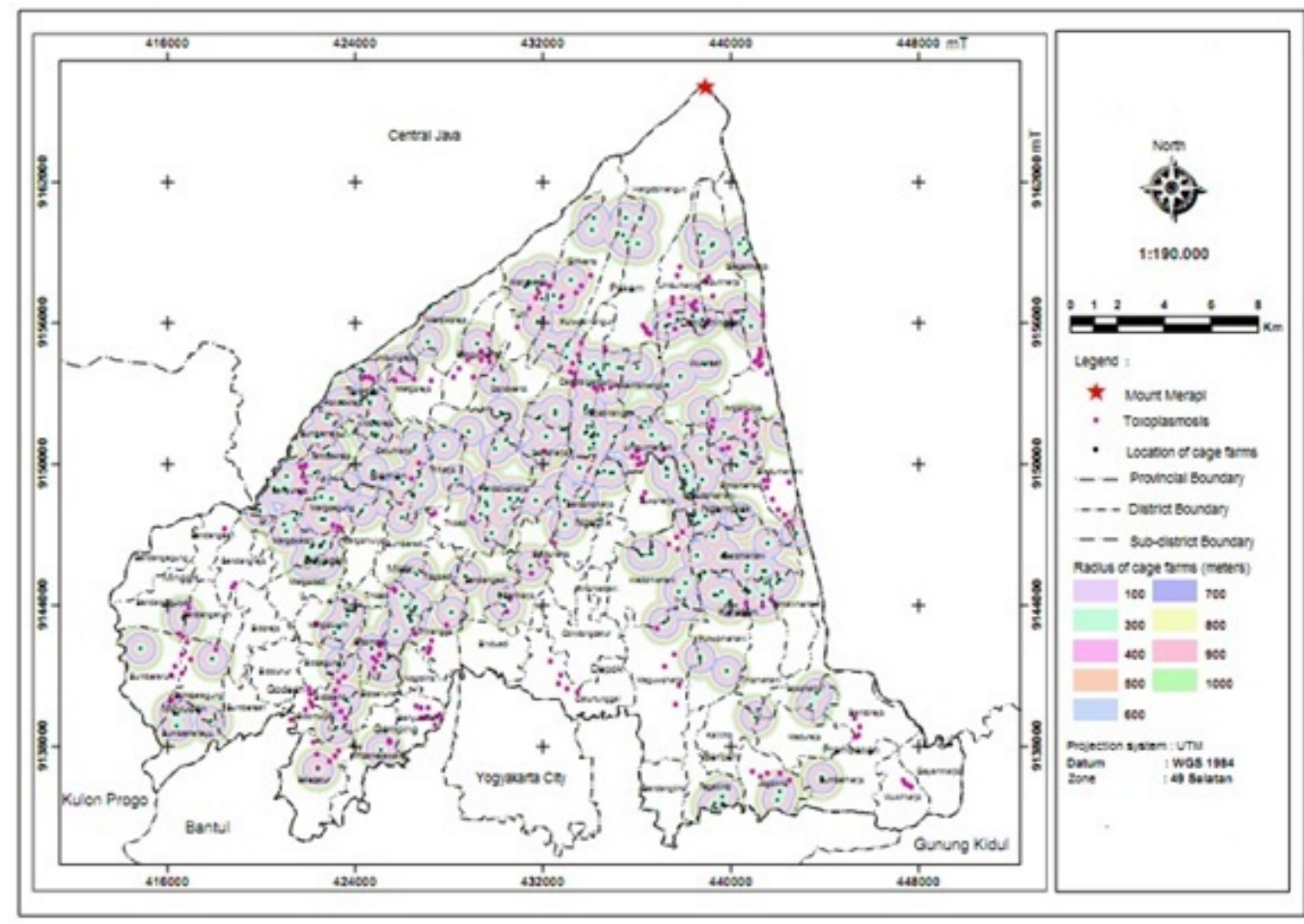

FIGURE 3 Distribution of toxoplasmosis in around the farms in Sleman District. Prevalence of toxoplasmosis based on distance of cattle pens to settlements from $100 \mathrm{~m}$ (purple), $200 \mathrm{~m}$ (light green) and $300 \mathrm{~m}$ (pink) were $34.7 \%, 26.9 \%$ and $37.5 \%$ respectively. 


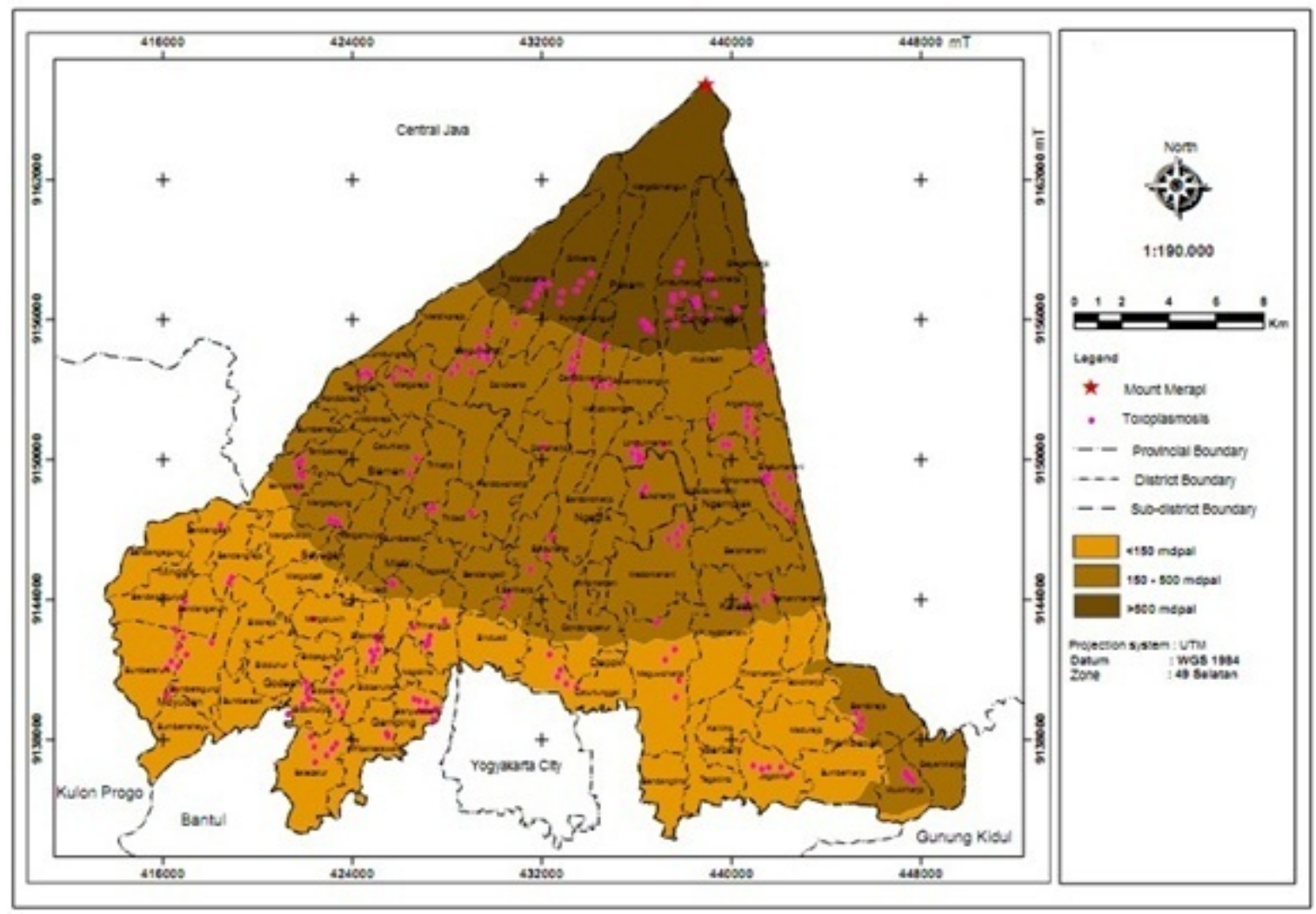

FIGURE 4 Distribution of toxoplasmosis in the various of altitude in Sleman District. The areas with high altitude (sepia), medium altitude (brown), and low altitude (russet) showed prevalence of toxoplasmosis were $41.1 \%, 61.9 \%$, and $66.3 \%$ respectively.

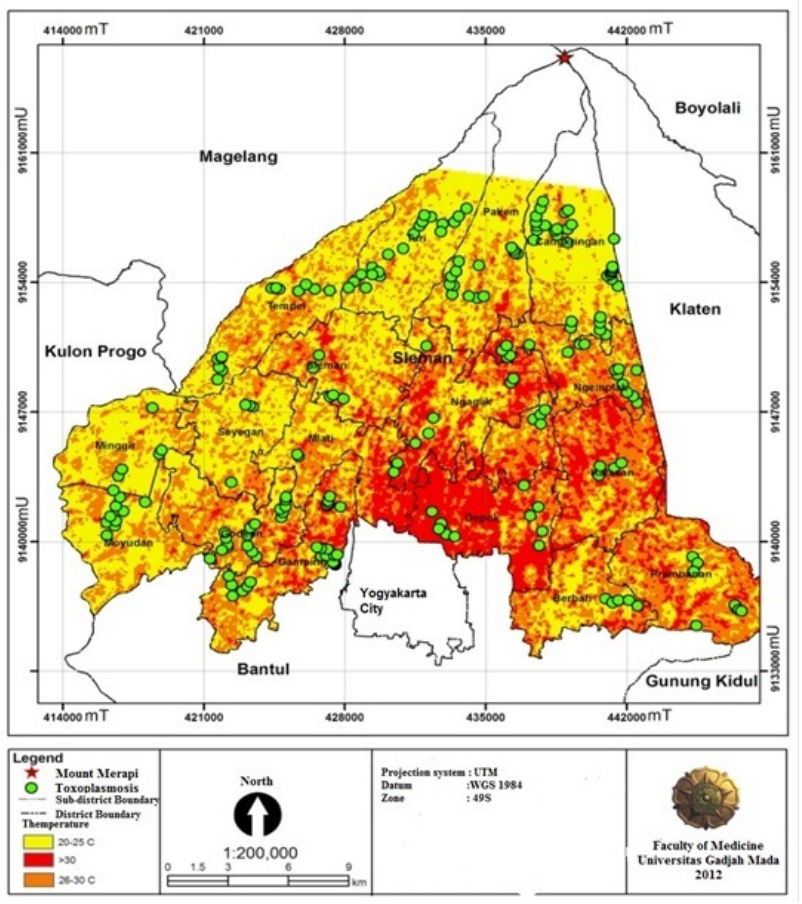

FIGURE 5 Distribution of toxoplasmosis based on soil surface temperature in Sleman district. The areas with surface temperature $20-25^{\circ} \mathrm{C}$ (yellow), $26-30^{\circ} \mathrm{C}$ (brown), and \& gt; $30^{\circ} \mathrm{C}$ (red) showed prevalence of toxoplasmosis were $54.4 \%, 66.4 \%$, and $48.2 \%$ respectively.
(Utami 2009; Döşkaya et al. 2014).

The study conducted by Utami (2009) showed that the serology assay used GRA-1 ELISA was sensitive and specific. Characteristic performance of IgM GRA-1 ELISA showed a sensitivity of $94.12 \%$ and specificity of $94.12 \%$, while the test of IgG GRA-1 ELISA showed a sensitivity of $94.12 \%$ and specificity of $100 \%$. This result similar to previously reported research showed the sensitivity, the specificity, and the positive predictive values of GRA-1 as an antigen are $100 \%, 86.36 \%$, and $94.11 \%$, respectively (Muflikhah and Artama 2017). Based on these data, the recombinant protein of GRA-1 is known to have high immunogenic activity in patients with toxoplasmosis compared with other excretory proteins of T. gondii. Generally, antigens commonly used for ELISA assay derived from surface and membrane proteins of T. gondii. Membrane antigens can be recognized by the immune system after T. gondii is destroyed by the host immune system during an ongoing infection, while the GRA-1 proteins are released and early recognized by host immune system when the parasites infecting host cells. (Utami 2009; Muflikhah and Artama 2017). Toxoplasma gondii can infect the intermediate host in a very wide range of animals. Toxoplasmosis in cats, livestock and wild animals can be a source of transmission to humans. Multi Center Study in Europe reported that eating cyst-contained meat are estimated to be infected by $T$. gondii in approximately $30-63 \%$ of cases, while contact with soil $6-17 \%$ and $14-49 \%$ of unknown risk factor (Fromont et al. 2009). The differences preva- 
lence of toxoplasmosis depends on conditions in regions, climates, farming methods, customs, meat consumption habits, and contact with cats (Elmore et al. 2010; Subedi et al. 2018).

The eruption of Merapi has changed many environmental conditions, that affect the ecology of existing species, including the vegetation inside. Vegetation is significant for breeding Annelida and arthropods such as flies and cockroaches, which acts as a vector to move oocysts in the environment to livestock or humans (Meerburg and Kijlstra 2009). The eruption also affected environmental damage and the animal population especially, those are the definitive and intermediate host of toxoplasmosis. Meat from animals such as goats, sheep, pigs, cattle, poultry and other livestock plays an essential role as a source transmission of T. gondii to humans (Iskandar 2008). Data from the local authority of farm in Sleman district showed about 1,900 castles die due to eruption; goat 2,400; and many other animals such as rabbits, chickens, and poultry. The intermediate hosts such as animal farms and the environment, are factors that can break the chain of disease caused

TABLE 2 The result of toxoplasmosis test based on altitude, soil surface temperature, and population of cats in the settlement.

\begin{tabular}{|c|c|c|c|c|}
\hline \multirow{2}{*}{ Characteristic } & \multicolumn{3}{|c|}{ Seropositive } & \multirow{2}{*}{$P$} \\
\hline & $\begin{array}{l}\text { No. of subjects } \\
\text { tested }\end{array}$ & positive tested & (\%) & \\
\hline \multicolumn{5}{|l|}{ Gender } \\
\hline - Male & 184 & 105 & 57 & .526 \\
\hline - Female & 201 & 119 & 59.2 & \\
\hline \multicolumn{5}{|c|}{ Altitude (geografis) } \\
\hline$-0-150 m$ & 98 & 65 & 66.3 & \\
\hline$-150-500 m$ & 197 & 122 & 61.9 & $.001^{*}$ \\
\hline$->500 \mathrm{~m}$ & 90 & 37 & 41.1 & \\
\hline \multicolumn{5}{|c|}{ Soil surface temperature } \\
\hline$-20^{\circ} \mathrm{C}-25^{\circ} \mathrm{C}$ & 180 & 98 & 54.4 & \\
\hline$-26^{\circ} \mathrm{C}-30^{\circ} \mathrm{C}$ & 149 & 99 & 66.4 & $.023^{*}$ \\
\hline$->30^{\circ} \mathrm{C}$ & 56 & 27 & 48.2 & \\
\hline \multicolumn{5}{|c|}{ Population of cats in settlement } \\
\hline - rare $(0-1$ cat $)$ & 147 & 72 & 49 & \\
\hline - little (1- 3 cats ) & 147 & 83 & 56.5 & $.001^{*}$ \\
\hline - much (>3 cats) & 91 & 69 & 75.8 & \\
\hline
\end{tabular}

TABLE 3 Result of multivariate analysis by Logistic Binary Regression test against character of environment that had significant correlation with toxoplasmosis in Sleman, Yogyakarta.

\begin{tabular}{llll}
\hline Characteristics & Odds Ratio & $\begin{array}{l}95 \% \text { Confidence } \\
\text { Interval }\end{array}$ & $\mathrm{p}$ \\
\hline $\begin{array}{l}\text { Altitude } \\
\begin{array}{l}\text { Surface } \\
\text { temperature }\end{array}\end{array}$ & 0.593 & $0.440-0.801$ & $0.001^{*}$ \\
$\begin{array}{l}\text { Population of } \\
\text { cats }\end{array}$ & $1.327^{*}$ & $1.020-1.726$ & $0.023^{*}$ \\
\hline
\end{tabular}

${ }^{*}$ Significant $(\mathrm{P}$ value $<0.05)$ by T. gondii. The population of cats around the area of eruption did affect to the number of oocysts that contaminated the environment (Dubey 1998; Fromont et al. 2009).

Cats have a significant role in the epidemiology of toxoplasmosis through shedding oocysts in feces during their prepatent period. Cats can be an intermediate host for the parasite with the occurrence of clinical signs; however, infection of T. gondii in cats is usually asymptomatic. Cats can become infected by eating the carcasses of small mammals (rats, mice, and birds) or ingesting oocysts from the environment (Sroka et al. 2018). Rats are considered the most important as intermediate hosts of $T$. gondii. Domestic cats are obligate carnivores and annually consume birds and small mammal as prey. Feral cats are potential reservoirs for the parasite of $T$. gondii because they have easy access to food resources, such as farms garbage bins (Salman et al. 2018). The study has carried out by Salman et al. (2018) showed that the prevalence of toxoplasmosis in cats aged 1-5 years, 6-10 years, and older than 11 years were $26.3 \%, 17.6 \%$, and $8.2 \%$, respectively. Cats that lived outdoors or had access to the outside have a higher risk of infection than indoor cats. The contamination of the environment by cat feces is a serious risk factor of spreading toxoplasmosis to human beings or animals. The existence of many wild cats also increases the possibility of the environmental contamination by the cat's feces. A study conducted in Egypt described that 97.4\% wild cats $T$. gondii oocysts positive in the feces contaminated their surroundings (Al-Kappany et al. 2010). The large population of the wild cats would increase the contamination of the environment caused by cat's feces, which is correlated with widespread toxoplasmosis infection to human beings or other animals (Subrata et al. 2015).

The toxoplasmosis disease transmission depends on the hydrologic characteristics of the river because the river characteristics related to water conditions in the crosssection of the river. Based on indications of proximity to cross the river, toxoplasmosis is found around the river. Oocyst contaminates the environment through the surface of the water as a river following the flow of rainwater. Residents who live around the river were possibly infected by oocyst caused by using river water as daily necessary, watering the yard or other needs. Therefore, existing oocysts in these watersheds will potentially transmit toxoplasmosis to humans or surrounding pets. Oocyst-contaminated water is a carrier that can spread toxoplasmosis in humans and animals. Oocysts are very resistant in an aqueous environment and are resistant to many disinfectants, including chemicals like chlorine (Aubert and Villena 2009).

Toxoplasmosis transmission in the residents who live around the cattle shed is due to contamination of food or drinking water by the oocysts that are derived from cattle pens carried by flies or cockroaches. Cats seek food around the cage that can defecate in the corral. Cattle sheds are a suitable place for the sporulation of oocysts due to the conditions and moisture, which are optimum for the oocyst sporulation process. Oocysts sheds in the environment can contaminate water wells, which are located around the 


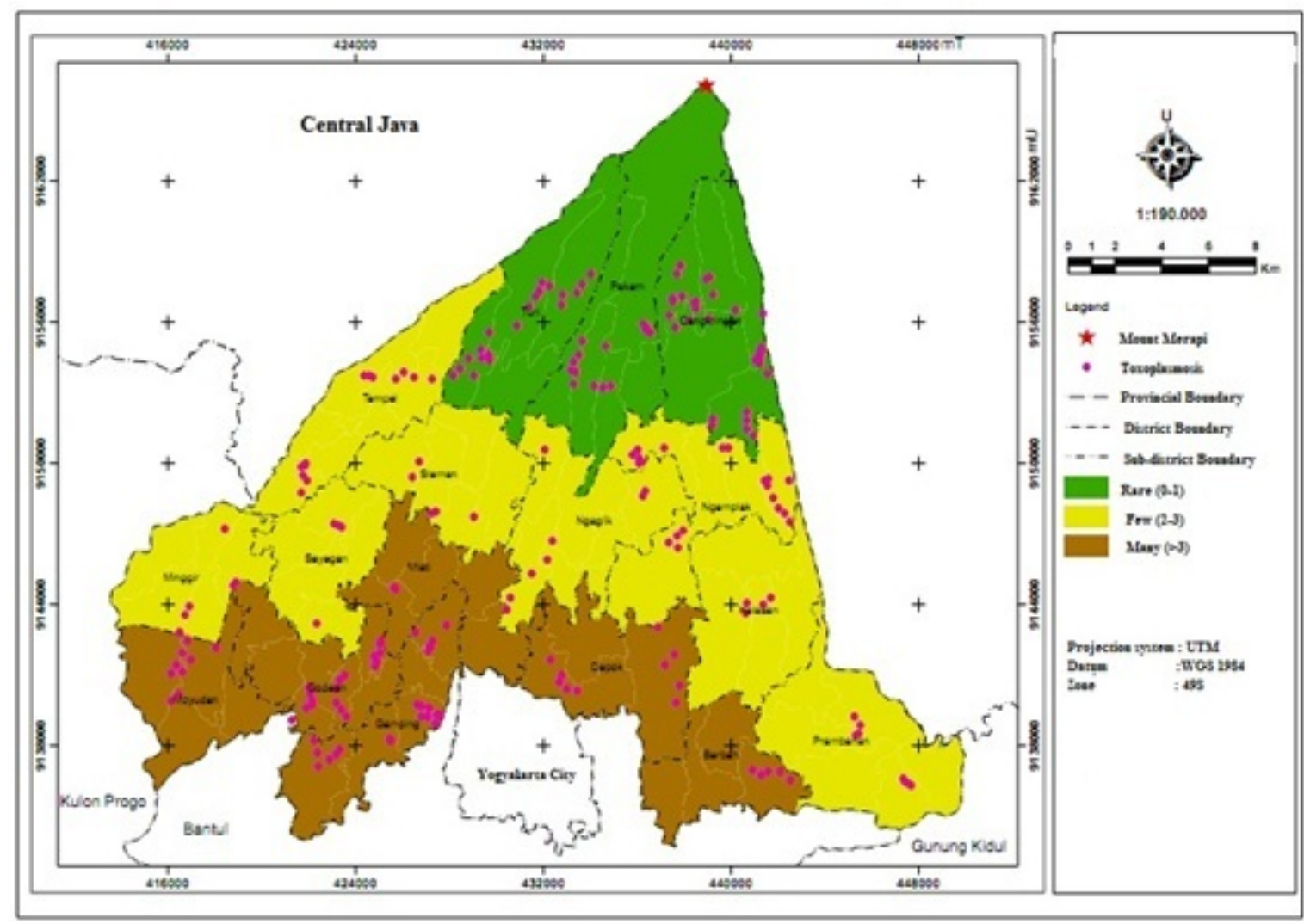

FIGURE 6 Distribution of toxoplasmosis based on cat populations in settlement in Sleman district. The areas with rare cat populations (green), a small cat populations (yellow), and large cat populations (brown) showed prevalence of toxoplasmosis were $49 \%, 56.5 \%$, and $75.8 \%$ respectively.

neighborhood. Oocysts that contaminate the environment can be distributed through the air, surface water, rainwater, and crops, as it also can spread through worms soil and compost (De Camps et al. 2008; Tenter 2009). The flies and mice have a very important role against $T$. gondii oocysts transferring to farm animals or pets. The research about seroepidemiology of $T$. gondii from China has found increasing seroprevalence of $T$. gondii in food animals those life at river run area (Dong et al. 2018). Results suggested that $T$. gondii oocysts may be transmitted through water, and annual precipitation possibly help the oocyst spread and retain accessible for the potential host.

Weather and geographic location significantly affect to the spread of $T$. gondii in the environment. $T$. gondii does not undergo sporulation, survive and become infectious without the influence of climatic conditions (Subedi et al. 2018). Sleman district is a wet tropical climate with an average temperature of $26.1^{\circ} \mathrm{C}$ to $27.1^{\circ} \mathrm{C}$ and the humidity is $70 \%$ to $95 \%$ (Meteorological, Climatological and Geophysics Agency, Yogyakarta). Temperature and hu-

TABLE 4 Result of multivariate analysis by Logistic Binary Regression test against character of environment that had significant correlation with toxoplasmosis in Sleman, Yogyakarta.

\begin{tabular}{|c|c|c|c|c|c|}
\hline Characteristics & Amount of sample & Positive tested & $\%$ & Wide $\left(\mathrm{km}^{3}\right)$ & $\mathrm{p}$ \\
\hline \multicolumn{6}{|c|}{ Distance of rivers } \\
\hline - 25 meter & 54 & 32 & 59.2 & 53.3 & \\
\hline - 50 meter & 82 & 45 & 54.8 & 53.3 & $0.016^{*}$ \\
\hline - 100 meter & 91 & 42 & 46.1 & 110.14 & \\
\hline$-\geq 200$ meter & 158 & 105 & 66.4 & 248.25 & \\
\hline \multicolumn{6}{|c|}{ Distance of cattle pens } \\
\hline - 100 meter & 46 & 16 & 34.7 & - & \\
\hline - 200 meter & 52 & 14 & 26.9 & - & $0.001^{*}$ \\
\hline - 300 meter & 64 & 24 & 37.5 & - & \\
\hline - >300 meter & 223 & 170 & 76.2 & - & \\
\hline
\end{tabular}

${ }^{*}$ Significant ( $\mathrm{P}$ value $<0.05$ ) 
midity in Sleman are ideal conditions for the sporulation of $T$. gondii oocysts. The variation of temperature in each region in Sleman is due to differences in land usage. Land usage for building leads to temperature increasing in the region compared to areas with lots of green vegetation or crop rice fields so that the temperature differences can affect the process of sporulation oocysts to infective form. There is a difference in the temperature range at present with the temperature in the previous year. Ninety five percent of the area in Sleman shows the temperature conditions are suitable for the process of sporulation oocysts to become infective form. The sporulation process of Toxoplasma gondii oocyst occurs at $20^{\circ} \mathrm{C}-28{ }^{\circ} \mathrm{C}$ (Sasmita 2006). This range is in accordance with the sporulation process proposed by Dubey who conducted the study in moist soil with temperatures ranging between $23^{\circ} \mathrm{C}-29^{\circ} \mathrm{C}$ (Dubey 1998).

The sporulation process usually ranges from 1 to 5 days, depending on the humidity and temperature of the surrounding environment (Tenter et al. 2000). At a temperature of $35{ }^{\circ} \mathrm{C}$ the sporulation process takes about 32 days (Meerburg and Kijlstra 2009). Increased sporulation oocysts in the environment will result in an increased human risk factor toxoplasmosis. Surface temperature in Sleman after the eruption of Merapi and the effect of global warming was ranging between $23^{\circ} \mathrm{C}-36^{\circ} \mathrm{C}$. Temperatures above $30^{\circ} \mathrm{C}$ cause the sporulation process of oocyst to be in the infective form becomes longer. As a result there will be an effect on the incidence of toxoplasmosis. Sporulated oocysts form are very resistant in environment and infective for a year or more at a temperature of $24^{\circ} \mathrm{C}$, but if it's at a temperature of $30^{\circ} \mathrm{C}$ it is only lasting for 20 days and at $50{ }^{\circ} \mathrm{C}$ or more then will quickly die (Iskandar 2008; Meerburg and Kijlstra 2009). The prevalence of toxoplasmosis in Sleman district was $54.4 \%\left(20-25{ }^{\circ} \mathrm{C}\right)$, $66.4 \%\left(26-30{ }^{\circ} \mathrm{C}\right)$ and $48 \%\left(>30{ }^{\circ} \mathrm{C}\right)$ respectively. These results indicate that an environment with a temperature above $30^{\circ} \mathrm{C}$ led to the oocyst sporulation process being longer, so that influences against the prevalence of toxoplasmosis in humans. The prevalence of toxoplasmosis in the district of Depok, Sleman, Yogyakarta (temperature $>30^{\circ} \mathrm{C}$ ) was $85 \%$, the factors that cause high incidence of toxoplasmosis in this area because of the habit of eating undercooked meat or consuming fresh vegetables which are not washed adequately. According to the European Multi Center Case Control Study, a comparison between the transmission through the existing cysts in meat and oocysts in cat feces to humans result in 5-10 times higher risk in people who consume meat (Dubey 1998).

Based on altitude, the prevalence of toxoplasmosis in Sleman, Yogyakarta can be influenced by several factors including the presence of oocysts in the environment and public behavior. The number of oocysts at an altitude of more than $500 \mathrm{~m}$, less than the height 0-150 m due to number of oocysts in each height is influenced by the environmental damage caused by the eruption of Merapi. Population of cats is as a source of oocyst contamination into the surrounding environment at an altitude of $500 \mathrm{~m}$ has decrease, so that oocyst contaminate the environment is reduced. Besides that, the oocysts in high areas can be carried by rain water through the river to areas of lower altitude, so the number of oocysts in these areas will increase. The areas that showed a high prevalence toxoplasmosis (71-85\%) as Berbah, Gamping, Depok, Godean, and Moyudan, Sleman have a slope area of $0-2 \%$, while the regions that have a slope area of $8-15 \%$ such as Tempel, Sleman, Turi, Ngemplak, Pakem, and Cangkringan showed a lower prevalence of toxoplasmosis that is 32$57 \%$.

Research conducted by Chacin-Bonilla et al. (2001) reported that residents living in the mountains with an altitude of $800 \mathrm{~m}$ from the sea surface with a temperature of $24{ }^{\circ} \mathrm{C}$ showed a lower prevalence of toxoplasmosis than population living in low lying areas which have a temperature of $30^{\circ} \mathrm{C}$ and altitude below $100 \mathrm{~m}$ from sea level. At an altitude of $500 \mathrm{~m}$, the area showed a high prevalence of toxoplasmosis is Cangkringan (60\%), where the area is most severely affected by the eruption of Merapi. The high prevalence of toxoplasmosis in this area is probably due to poor hygiene in the consumption of food or drink. Community in this area is living in shelters. Sources of toxoplasmosis transmission come from vegetables or drinking water sources, where the vegetables are not washed clean because of limited water. Decline in public health conditions also resulted in the emergence of reinfection cases of toxoplasmosis. The presence of cats is found in areas close to urban areas. Urban areas are usually very densely populated and there are many sources of food for cats (Meireles et al. 2004; Salman et al. 2018).

The area in low altitude, and having a subtropical climate (hot and humid), had a higher prevalence of toxoplasmosis. The probable reasons for high seroprevalence are semi-intensive sheep farming, humid conditions in the study area at low altitude, the presence of feral cats, and open feed storage with access to cats. Similarly, higher prevalence of T. gondii in Pokhara district, Nepal, can be attributed to the high rainfall and semi intensive sheep farming (Subedi et al. 2018). The study by (CaballeroOrtega et al. 2008) who revealed that the highest prevalence of $T$. gondii is presented at low altitude. A 10 years study in France revealed the relationship of T. gondii prevalence with temperature and rain (Caballero-Ortega et al. 2008). The risk of acquiring infection was enhanced when the weather was moist and warm. Oocyst survival increases in moist conditions during longer periods of hot weather (Meerburg and Kijlstra 2009). The study carrying out by Subedi et al. (2018) reveals that prevalence of toxoplasmosis in sheep at low altitude and has subtropical climate (hot and humid) is higher than areas with high altitude and the arid environment.

The amount of domestic waste by poor management in dense populated areas is one of the causes of an increase cat and mouse populations. Seroprevalence of toxoplasmosis infected cats is estimated from 0.23 to 0.39 per cat per year. The average soil contaminated with oocysts from infected cats are estimated about 94 to $4671 / \mathrm{m}^{2}$ each year, 
it depends on the cat population which is infected by $\mathrm{T}$. gondii and the oocysts which are excreted (Afonso et al. 2010). The cat population will affect the high oocyst that will pollute the environment if the cat is infected by $T$. gondii. Latent toxoplasmosis is common among domestic cats, corresponding to a high prevlence in adult cats. Environments that are contaminated by oocysts of T. gondii could potentially spread the infection to an uninfected cats, livestock and humans (Meireles et al. 2004; Salman et al. 2018).

\section{Conclusions}

The prevalence of toxoplasmosis in Sleman, Yogyakarta after eruption of Merapi was 58\% and the distance of rivers and cattle pens had affected against toxoplasmosis. There are differences seroprevalence of toxoplasmosis based on altitude, soil surface temperature and presence of cats in human settlements checked by ELISA using recombinant proteins GRA-1 T.gondii local isolates.

\section{Acknowledgments}

The authors are grateful to One Health/ EcoHealth Resource Center-UGM for providing the opportunity for this research. We also thank to Mrs Arsiah for her assistance in Biochemistry Laboratory, Research Center for Biotechnology, Universitas Gadjah Mada, Great thank also to the International Livestock Research Institute (ILRI) that was financially supported this work.

\section{Authors' contributions}

WTA: funding acquisition, study design, led the research, drafting manuscript, collection of data, data analysis, and revising intellectual content. BSW: aided in interpreting the results and worked on the manuscript, and revising intellectual content, contributed to the final version of the manuscript.

\section{Competing interests}

The authors declare no competing interest.

\section{References}

Afonso E, Thulliez P, Gilot-Fromont E. 2010. Local meteorological conditions, dynamics of seroconversion to Toxoplasma gondii in cats (Felis catus) and oocyst burden in a rural environment. Epidemiol Infect. 138(8):1105-1113. doi:10.1017/S0950268809991270.

Agustin PD, Mukono J. 2016. Description Between Cats Exposure with Toxoplasmosis Disease on Cats Owner and Not- Cats Owner in Mulyorejo Subdistrict, Surabaya City. Jurnal Kesehatan Lingkungan 8(1):103. doi:10.20473/jkl.v8i1.2015.103-117.
Al-Kappany YM, Rajendran C, Ferreira LR, Kwok OC, Abu-Elwafa SA, Hilali M, Dubey JP. 2010. High prevalence of toxoplasmosis in cats from Egypt: Isolation of viable Toxoplasma gondii, tissue distribution, and isolate designation. J Parasitol. 96(6):11151118. doi:10.1645/GE-2554.1.

Aubert D, Villena I. 2009. Detection of Toxoplasma gondii oocysts in water: Proposition of a strategy and evaluation in Champagne-Ardenne region, France. Mem Inst Oswaldo Cruz. 104(2):290-295. doi:10.1590/S0074-02762009000200023.

Caballero-Ortega H, Palma JM, García-Márquez LJ, Gildo-Cárdenas A, Correa D. 2008. Frequency and risk factors for toxoplasmosis in ovines of various regions of the State of Colima, Mexico. Parasitology 135(12):1385-1389. doi:10.1017/S0031182008004873.

Chacin-Bonilla L, Sanchez-Chavez Y, Monsalve F, Estevez J. 2001. Seroepidemiology of Toxoplasmosis in Amerindians from Western Venezuela. Am J Trop Med Hyg. 65(2):131-135. doi:10.4269/ajtmh.2001.65.131.

Chahaya I. 2003. Toxoplasma gondii Epidemiology of Toxoplasma gondii. Jurnal Kesehatan p. 1-13.

Chivian E. 2001. Environment and health: 7. Species loss and ecosystem disruption - The implications for human health. CMAJ 164(1):66-69.

De Camps S, Dubey JP, Saville WJ. 2008. Seroepidemiology of Toxoplasma gondii in zoo animals in selected zoos in the midwestern United States. J Parasitol. 94(3):648-653. doi:10.1645/GE-1453R.1.

Döşkaya M, Caner A, Can H, Iz SG, Gedik Y, Döşkaya AD, Kalantari-Dehaghi M, Gürüz Y. 2014. Diagnostic value of a Rec-ELISA Using Toxoplasma gondii recombinant SporoSAG, BAG1, and GRA1 proteins in murine models infected orally with tissue cysts and oocysts. PLoS ONE 9(9). doi:10.1371/journal.pone.0108329.

Dong H, Su R, Lu Y, Wang M, Liu J, Jian F, Yang Y. 2018. Prevalence, risk factors, and genotypes of Toxoplasma gondii in food animals and humans (2000-2017) from China. Front Microbiol. 9:1-10. doi:10.3389/fmicb.2018.02108.

Dubey JP. 1998. Toxoplasma gondii oocyst survival under defined temperatures. J Parasitol. 84(4):862-865. doi:10.2307/3284606.

Elmore SA, Jones JL, Conrad PA, Patton S, Lindsay DS, Dubey JP. 2010. Toxoplasma gondii: epidemiology, feline clinical aspects, and prevention. Trends Parasitol. 26(4):190-196. doi:10.1016/j.pt.2010.01.009.

Fromont EG, Riche B, Rabilloud M. 2009. Toxoplasma seroprevalence in a rural population in France: Detection of a household effect. BMC Infect Dis. 9(76):1-7. doi:10.1186/1471-2334-9-76.

Iskandar T. 2008. Toxoplasmosis of Goat and Sheep in Java. Wartazoa 18(3):157-166. doi:10.14334/wartazoa.v18i3.900.

Jones JL, Kruszon-Moran D, Wilson M, McQuillan G, 
Navin T, McAuley JB. 2001. Toxoplasma gondii infection in the United States: Seroprevalence and risk factor. Am J Epidemiol. 154(4):357-365. doi:10.1093/aje/154.4.357.

Lopes AP, Sargo R, Rodrigues M, Cardoso L. 2011. High seroprevalence of antibodies to Toxoplasma gondii in wild animals from Portugal. Parasitol Res. 108(5):1163-1169. doi:10.1007/s00436-010-2158-6.

Meerburg BG, Kijlstra A. 2009. Changing climatechanging pathogens: Toxoplasma gondii in NorthWestern Europe. Parasitol Res. 105(1):17-24. doi:10.1007/s00436-009-1447-4.

Meireles LR, Galisteo AJ, Pompeu E, Andrade HF. 2004. Toxoplasma gondii spreading in an urban area evaluated by seroprevalence in free-living cats and dogs. Trop Med Int Health. 9(8):876-881. doi:10.1111/j.1365-3156.2004.01280.x.

Muflikhah ND, Artama WT. 2017. An evaluation study of enzyme-linked immunosorbent assay (ELISA) using recombinant protein Gra1 for detection of IgG antibodies againts Toxoplasma gondii infections. Indonesian Journal of Tropical and Infectious Disease 6(5):105. doi:10.20473/ijtid.v6i5.5903.

Rapport DJ. 2007. Sustainability science: An ecohealth perspective. Sustain Sci. 2(1):77-84. doi:10.1007/s11625-006-0016-3.

Retmanasari A, Widartono BS, Wijayanti MA, Artama WT. 2017. Prevalence and Risk Factors for Toxoplasmosis in Middle Java, Indonesia. EcoHealth 14(1):162-170. doi:10.1007/s10393-016-1198-5.

Sadiqui S, Shah SRH, Almugadam BS, Shakeela Q, Ahmad S. 2019. Distribution of Toxoplasma gondii IgM and IgG antibody seropositivity among age groups and gestational periods in pregnant women. F1000Research 7:1823. doi:10.12688/f1000research.15344.3.

Salman D, Pumidonming W, Oohashi E, Igarashi M. 2018. Prevalence of Toxoplasma gondii and other intestinal parasites in cats in tokachi sub-prefecture, Japan. J Vet Medi Sci. 80(6):960-967. doi:10.1292/jvms.170713.

Sasmita R. 2006. Toxoplasmosis causes miscarriages and baby abnormalities. Surabaya: Airlangga University Press.

Sroka J, Karamon J, Dutkiewicz J, Fatla AW, Zając V, Cencek T. 2018. Prevalence of Toxoplasma gondii infection in cats in southwesternpoland. Ann Agric Environ Med. 25(3):576-580. doi:10.26444/aaem/94675.

Subedi S, Sharma B, Singh S, Bindari YR. 2018. Seroprevalence of Toxoplasma gondii in sheep in different geographical regions of Nepal. Vet Anim Sci. 5:7-9. doi:10.1016/j.vas.2018.01.001.

Subekti DT. 2014. Study of Antigenicity and Immunogenicity Gra1 Protein from Toxoplasma gondii. Indones Bull Anim Vet. 23(3):103-114. doi:10.14334/wartazoa.v23i3.1001.

Subekti DT, Arrasyid NK. 2006. Immunopathogenesis of Toxoplasma gondii according to different strains. Wartazoa 16(3):128-145.

Subekti DT, Artama WT, Sulistyaningsih E, Poerwanto SH, Sari Y, Bagaskoro F. 2008. Cloning and Clone analysis of GRA1 gene from local isolate Toxoplasma gondii tachyzoite. JITV 13(1):43-51.

Subrata IM, Suryadhi NT, Mantik-Astawa N, Damriyasa IM. 2015. Epidemiological and Molecular Analysis of Toxoplasma gondii in Faecal Samples of Cats Obtained From House of Maternal in Bali. Bali Med J 4(2):68. doi:10.15562/bmj.v4i2.122.

Sujono. 2010. Serological prevalence of toxoplasmosis and risk factor at privilege province of Yogyakarta with ELISA method using Gra1 tachyzoite recombinant proteins of local isolate. Master thesis, Yogyakarta, Gadjah Mada University.

Sukthana Y. 2006. Toxoplasmosis: beyond animals to human. Trends Parasitol. 22:137-142.

Tenter AM. 2009. Toxoplasma gondii in animals used for human consumption. Mem Inst Oswaldo Cruz. 104(2):364-369. doi:10.1590/S007402762009000200033.

Tenter AM, Heckeroth AR, Weiss LM. 2000. Toxoplasma gondii: From animals to humans. Int J Parasitol. 30(12-13):1217-1258. doi:10.1016/S00207519(00)00124-7.

Utami WS. 2009. Isolation, characterization and diagnostic test of recombinant GRA-1 takizoit of Toxoplasma gondii local isolates. Master thesis, Yogyakarta, Gadjah Mada University.

Wihadmadyatami H, Widayanti R, Artama WT. 2011. Isolation and identification expression of Granule-1 (GRA1) recombinant protein Toxoplasma gondii local isolate. J Sain Vet 29(2):102-109. 